удК 174:005

\title{
ПРО ВПЛИВ КОРПОРАТИВНОЇ КУЛЬТУРИ НА УПРАВЛІНСЬКІ ПРОЦЕСИ
}

\section{ON THE INFLUENCE OF CORPORATE CULTURE ON MANAGEMENT PROCESSES}

\author{
Стамбульська Христина Богданівна \\ студентка, \\ Національний університет «Львівська політехніка» \\ ORCID: https://orcid.org/0000-0002-8601-4117 \\ Передало Христина Станіславівна \\ кандидат економічних наук, доцент, \\ Національний університет «Львівська політехніка» \\ ORCID: https://orcid.org/0000-0003-3972-6178
Stambulska Khrystyna, Peredalo Khrystyna
Lviv Polytechnic National University

\begin{abstract}
Розглянуто значення корпоративної культури у діяльності компаній. Підмічено, що наявність дієвої корпоративної культури чи окремих її елементів значно покращує роботу організації, її бізнес-процесів, має вагомий вплив на досягнення ключових фрінансових показників, збільшення чисельності клієнтів та споживачів, покращення морально-психологічного клімату в колективі тощо. На основі статистичних даних зауважено, що у вітчизняних компаніях корпоративній культурі приділяється не достатньо належної уваги, навіть за умови визнання її вагомості керівниками, на відміну від іноземних організацій, які створюють відповідні підрозділи для фрормування корпоративної культури, розробляють спеціальні програми для її впровадження в колектив працівників та механізми для поєднання окремих її елементів з конкретними цільовими показниками. Наведено результати досліджень впливу корпоративної культури чи її окремих елементів на загальні управлінські процеси, а саме: планування, організування, мотивування, контролювання та регулювання.

Ключові слова: корпоративна культура, місія, мета, цінності, планування, організування, мотивування, контролювання, регулювання, залученість, визнання.

Рассмотрено значение корпоративной культуры в деятельности компаний. Подмечено, что наличие действенной корпоративной культуры или отдельных ее элементов значительно улучшает работу организации, ее бизнес-процессов, имеет большое влияние на достижение ключевых фринансовых показателей, увеличение численности клиентов и потребителей, улучшение морально-психологического климата в коллективе и т.д. На основе статистических данных отмечено, что в отечественных компаниях корпоративной культуре уделяется недостаточно должного внимания, даже при условии признания ее значимости руководителями, в отличие от иностранных организаций, которые создают соответствующие подразделения для фрормирования корпоративной культуры, разрабатывают специальные программы для ее внедрения в коллектив работников и механизмы сочетания отдельных ее элементов с конкретными целевыми показателями. Представлены результаты исследований влияния корпоративной культуры или ее отдельных элементов на общие управленческие процессы, а именно: планирование, организацию, мотивирование, контролирование и регулирование.

Ключевые слова: корпоративная культура, миссия, цель, ценности, планирование, организация, мотивирование, контролирование, регулирование, вовлеченность, признание.
\end{abstract}

There has been analysed the importance of corporate culture in the activities of companies. It is noted that the presence of an effective corporate culture or its individual elements significantly improves the work of the organization, its business processes, also has a significant impact on the achievement of key financial indicators, increasing the number of customers and consumers, establishing relationships with external target groups, improving the moral and psychological climate. Based on statistics, it is noted that in domestic companies not enough attention is given to corporate culture, even if its importance is recognized by managers, in contrast to foreign organizations that create appropriate units for corporate culture, develop special programs for its implementation in the staff and mechanisms for combining some of its elements with specific target indicators. There have been shown the research results of 
the influence of corporate culture or its separate elements on the general administrative processes, namely: planning, organization, motivation, control and regulation. In particular, on the basis of the research by both business scholars and practitioners it has been shown that corporate culture influences the development of strategic plans, as key elements of corporate culture such as mission, vision, logo, slogan, history are also key elements of strategy, thus, contributing to the achievement of set goals for the growth of financial performance of the organization, customer loyalty, their credibility in a recognizable brand. The chosen type of corporate culture sets the main strategic directions of the company, in particular: the type "baseball team" contributes to the implementation of the strategy of rapid growth, and "academic club" contributes to the implementation of the strategy of moderate growth. Regulated values are of great importance in the organization, for which, in order to strengthen the impact, clear visual rules of their use in current activities must be prescribed. The key role of corporate culture is its stimulating function, which ensures proper involvement of employees, their recognition, which, consequently, contributing to their positive motivation to work, reducing staff turnover, absenteeism, mistakes and increasing productivity, number of customer and etc. Forming the basic postulates of the company, corporate culture creates a standard of action used in controlling business processes. And if they deviate from the declared statements - to regulate them.

Keywords: corporate culture, mission, purpose, values, planning, organization, motivation, control, regulation, involvement, recognition.

Постановка проблеми. На сьогодні, корпоративна культура є невід'ємним атрибутом компаній у бізнес-середовищі. Багато хто проголошує публічно свою місію чи бачення, має розроблений логотип чи слоган, у маркетингових заходах використовує історію заснування чи, в межах внутрішнього середовища для посилення мотивації працівників, - корпоративного героя. На сайтах організацій все частіше можна побачити цілісно структуровані корпоративні кодекси 3 детальним описом майже всіх елементів корпоративної культури. Однак, при цьому, її проголошені твердження, цінності чи правила, у багатьох випадках, носять лише формальний характер, або використовуються в маркетингових цілях. При такому підході, керівництво надає вказівки для їі розроблення лише для створення візуального привабливого образу організації, не задумуючись про сильний вплив корпоративної культури або окремих її лементів на окремі управлінські процеси або діяльність компаній загалом.

Аналіз останніх досліджень і публікацій. Вивченням ролі корпоративної культури у діяльності компаній займалося багато вітчизняних та іноземних науковців та практиків бізнесу, серед яких можна виокремити Балу О., Багданову Н., Бойко О., Ринкевич Н., Тарасевич О., Голанда К., Брауна Е., Оучі У., Шейна $€$. та інших. Ії̈ вплив виявився незаперечним. Наявна корпоративна культура, чи навіть окремі її структурні елементи, позитивно впливають на чітке визначення стратегічних орієнтирів та їх дотримання у поточній діяльності, на рівень мотивації не лише працівників, але й окремих цільових груп впливу тощо.

Як показали результатами опублікованих соціологічних досліджень, проведених серед українських бізнесменів тапредставлениху [1], щодо виявлення ставлення адміністративного персоналу до ролі корпоративної культури в організаціях, то:

- 55\% українських керівників стверджують, що корпоративна культура повинна бути прописаною на підприємстві;

- 40\% українських підприємців, фоормуючи культуру, за основу беруть західні технології та принципи;

- 35\% респондентів розуміють її значення та необхідність впровадження на підприємстві, однак не виділяють на це ані часу, ані ресурсів;

- 25\% керівників вважають, що корпоративна культура $є$ непотрібною.

За результатами опитування видно, що багато керівників вітчизняних підприємств усвідомлюють важливість наявної корпоративної культури та дотримання прописаних у ній цінностей, норм та правил.

У свою чергу дані опитування 62 американських компаній щодо важливості культури дещо відрізняються від відповідей українських респондентів, а саме [1]:

- 88\% компаній фрормують спеціальні підрозділи, на яких покладено відповідальність стосовно розроблення та дотримання корпоративної діяльності, аналізу ії впливу на діяльність компанії;

- 65\% компаній на практиці поєднують фрормування та впровадження цінностей, правил та норм із заходами для підвищення рентабельності та інших фрінансових показників;

- 58\% компаній для формування корпоративної культури розробили та використовують унікальні програми, для того щоб облегшити процес впровадження корпоративної культури.

Цікавими є результати дослідження впливу корпоративної культури на діяльність підприємства, проведені профресором бухгал- 
терського обліку Шивою Раджгопалом із Колумбійської бізнес-школи. Разом із своїми колегами 3 бізнес-школи Фукуа Дьюка він провів опитування, тривалістю 13 місяців, респондентами якого були близько 1400 північноамериканських генеральних і фрінансових директорів. Проведене ними дослідження показало такі результати [2]:

- більше 90\% керівників стверджують, що корпоративна культура $є$ однією із важливих складових для ведення діяльності;

- 92\% управлінців заявили, що на їхню думку покращення корпоративної культури срірми підвищить вартість компанії;

- більше 50\% опитуваних переконані, що культура впливає на продуктивність, креативність, прибутковість, вартість компанії та темпи її зростання;

- 15\% стверджують, що корпоративна культура їхньої компанії розвинена достатньо і успішно використовується в межах організації.

А дослідження, проведене виданням Forbs 2019 року [2], показало, що 73\% опитаних працівників стверджують, що ссрормовані цінності, норми, переконання та правила допомагають дотримуватись обраної стратегії.

Однак, незважаючи на значний вплив корпоративної культури на діяльність компаній, все таки є серед вітчизняних підприємств керівники, які не вважають за потрібне приділяти ії формуванню та розвитку належної уваги, гадаючи, що лише старі директивні методи управління $\epsilon$ успішними. Неусвідомленість ними впливу корпоративної культури чи її окремих елементів на загальні управлінські процеси не дозволяє в повному обсязі забезпечити їм належну реалізацію бізнес-процесів. Саме ця частина проблеми залишається і досі невирішеною та потребує додаткових досліджень.

Формулювання цілей статті. На підставі проведених досліджень ціллю є розглянути та проаналізувати практичні аспекти впливу корпоративної культури на загальні управлінські процеси як планування, організування, мотивування, контролювання та регулювання.

Виклад основного матеріалу дослідження. Важливість корпоративної культури у розрізі планування, а точніше сказати стратегічного планування, є незаперечним. Саме ключові елементи розроблення стратегії як місія, бачення, логотип, слоган, історія є, одночасно, і елементами корпоративної культури.

Місія організації - це ключова об'єднувальна ідея, яка місить в собі повідомлення щодо соціального призначення фрункціонування компанії з метою інфрормування та заохочення цільових груп впливу до співпраці та підтримки реалізації фрункцій менеджменту.

Часто, місію ототожнюють 3 загальною метою, яку розглядають як суть існування бізнесу, або як те, чим організація займається сьогодні і чого прагне досягнути. Згідно 3 щорічним опитуванням керівників найбільших компаній світу, проведене організацією РЕС [3], більшість, описуючи мету, говорили про створення цінності для зацікавлених сторін: акціонерів (16\%), постачальників, клієнтів, працівників і свого бізнесу (26\%) з точки зору досягнення фрінансових показників. Результати опитування наведені на рис. 1.

3 результатів опитування видно, що чітко ссрормована мета компанії як складова корпоративної культури впливає на фрормування цінностей різних цільових груп, стимулюючи їх, тим самим, до співпраці та згуртованості.

Підсилюючим елементом місії організації, чи ії̈ бачення, є логотип або слоган, які, фрормуючи імідж компанії, підсилюють рівень впізнання організації на ринку. Зокрема, за інсрормацією 3 [4], у 2021 році компанія Renderforest провела дослідження, за результатами якого виявлено, що 75 \% опитаних вважають, що

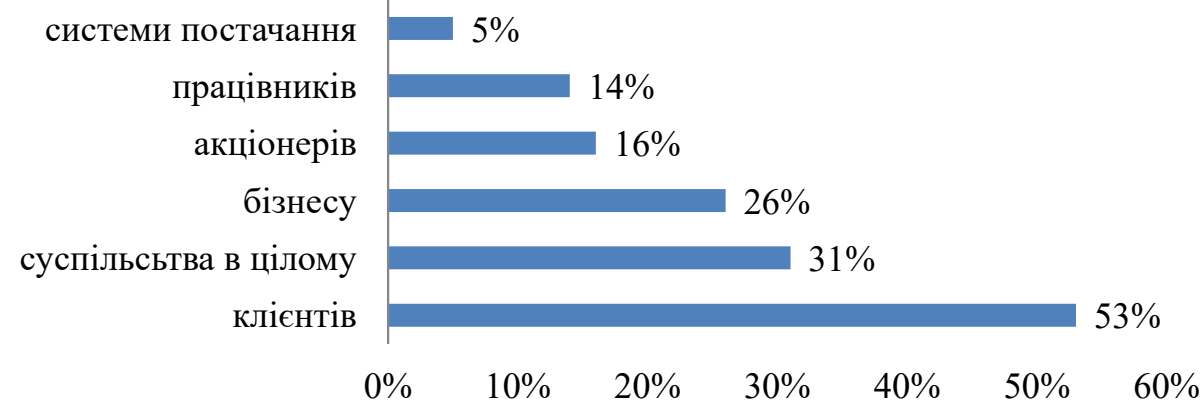

Рис. 1. Структура відповідей респондентів на питання: «Метою Вашої компанії сьогодні є створення цінності для...» 


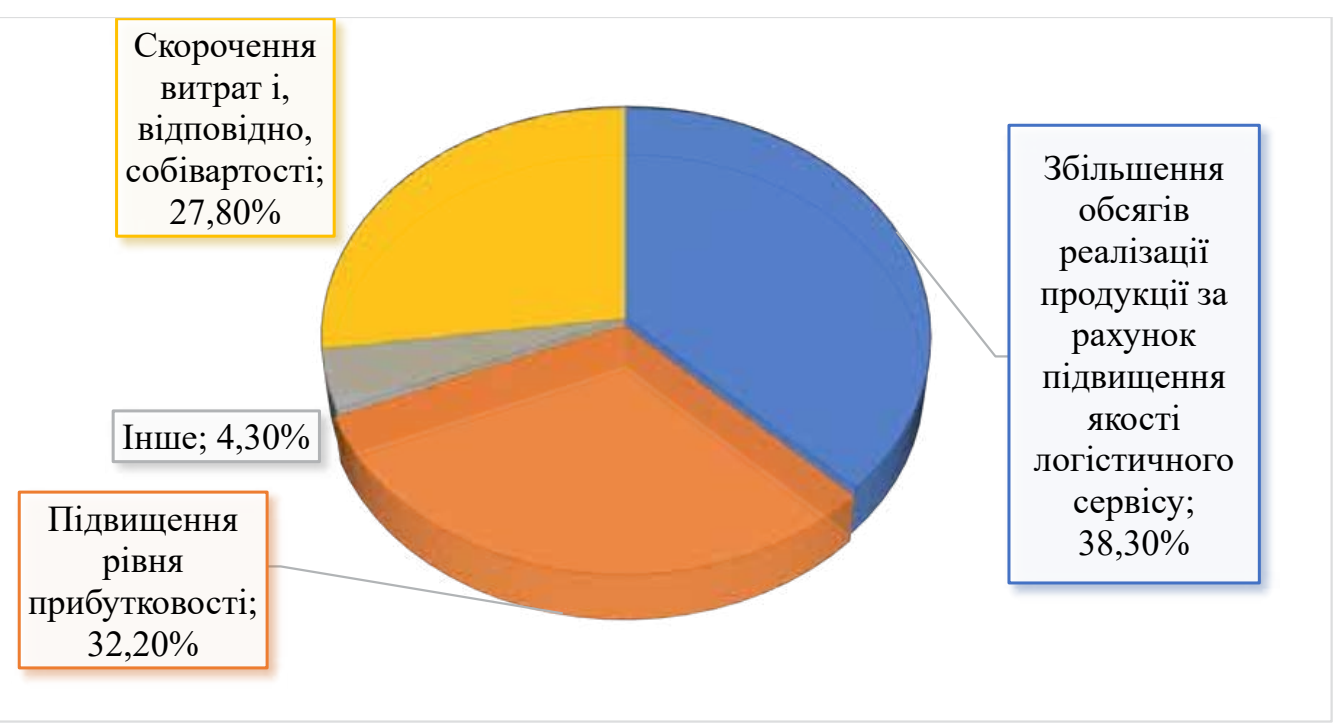

Рис. 2. Структура відповідей респондентів щодо впливу корпоративної культури на фрінансові результати організації

Джерело: [5]

логотипи є найбільш впізнаваними ідентифрікаторами бренду, 60\% стверджують, що впізнають компанії за візуальним стилем, 45\% колір бренду та $25 \%$ - унікальний голос.

Діюча корпоративна культура сприяє і досягненню встановлених фрінансових показників. Цьому $є$ підтвердження, базоване на проведеному у 2020 році дослідженні. Респондентами були керівники різних за сорерою діяльності українських компанії, 70\% з яких одностайно ствердили, що корпоративна культура впливає на фрінансові результати їх організацій [5]. Результати експертного опитування наведено на рис. 2.

Підтвердженням цього фракту $€$ дослідження, описане Джеймсом Хескетом, яке окреслює різницю в результатах за одинадцятирічний період між дванадцятьма компаніями, які ссрормували корпоративну культуру та активно її використовували, та двадцятьма компаніями, в яких вона відсутня. У табл. 1 представлено результати дослідження [6].
Отримані результати вражають кардинальною відмінністю, так $755 \%$ різниці у зростанні чистого доходу, $827 \%$ різниці у зростанні курсу акції $€$ яскравим прикладом того, що корпоративна культура сильно пов'язана із фрінансовими показниками, і цей сракт не можна ігнорувати.

Цікавим є фракт, що стратегія фрормує майбутню корпоративну культуру, і навпаки. Так, такі типи корпоративної культури як: приналежність, успіх, згода, синтез, клуб фрормують стратегію помірного зростання; типи домінування, бейсбольна команда, клуб жорстких хлопців - стратегію швидкого зростання; типи регламент та процесна культура - стратегію повільного зростання. Зрозуміло, що в процесі діяльності організації стратегія може змінюватись в силу обставин і, відповідно, корпоративна культура теж зазнає змін. Однак, при цьому слід уникати невідповідностей, оскільки неузгодженість між стратегією та культурою створює перешкоду для працівників компанії у реалізації та досягненні поставлених цілей.

Таблиця 1

Результати впливу корпоративної культури на фрінансові показники організацій

\begin{tabular}{|c|l|c|c|}
\hline $\begin{array}{c}\text { № } \\
\text { 3/п }\end{array}$ & \multicolumn{1}{|c|}{ Показники } & $\begin{array}{c}\text { Середнє збільшення } \\
\text { для 12 фрірм із наявною } \\
\text { корпоративною культурою }\end{array}$ & $\begin{array}{c}\text { Середнє збільшення } \\
\text { для 20 фрірм без наявності } \\
\text { корпоративної культури }\end{array}$ \\
\hline 1 & Зростання доходів & $682 \%$ & $166 \%$ \\
\hline 2 & Зростання зайнятості & $282 \%$ & $36 \%$ \\
\hline 3 & Зростання курсу акцій & $901 \%$ & $74 \%$ \\
\hline 4 & Зростання чистого доходу & $756 \%$ & $1 \%$ \\
\hline
\end{tabular}

Джерело: [6] 
За умови, коли дотримання стратегії вимагає від працівника дій, які не зовсім відповідають цінностям, нормам, і правилам компанії, це може призвести до неправильного тлумачення завдань та, в результаті, необґрунтованого та неправильно прийнятого рішення.

Організування як загальна фрункція менеджменту забезпечує формування структури управління підприємством, встановлення системи зв'язків та відносин, які дають змогу забезпечити трудовий процес 3 метою досягнення поставлених цілей. Для того, щоб забезпечити ефективний процес взаємодії працівників потрібні певні правила, норми, а зокрема принципи, цінності, які формуються у рамках корпоративної культури.

Корпоративні цінності організації - це певні переконання, які допоможуть подолати виклики ринку, реалізувати стратегію й досягти поставлених цілей, а також вплинути на процеси організування, зокрема: формують належні комунікації як в середині підрозділів, так і з зовнішніми цільовими групами, створюють єдину систему правил поведінки та процедур щодо вирішення поставлених завдань та появи проблем тощо [7].

Спершу, сорормовані цінності повинні відповідати проголошеній місії та баченню компанії. Так, наприклад, в компанії Work.ua, місія якої: «надавати найкращий сервіс пошуку роботи, щоб допомогти людям стати щасливішими», Є свої правила, традиції, цінності, як-от: «допомагати людям», «добре або ніяк», «просто і зрозуміло», «слухати і розмовляти», «більше меншими засобами», «чесність в усьому» [8].

Для підсилення їх дієвості, цінності варто розписати щодо можливості їх застосування в поточній діяльності. Так, наприклад, озвучена цінність «більше меншими засобами» дає змогу компанії Work.ua в певних побутових ситуаціях зекономити кошти на тому ж канцелярському приладді чи антисептичних засобах за рахунок вибору більш бюджетних варіантів, при цьому не знижуючи їх якість. Ним же керується і керівництво, шукаючи менш витратний спосіб отримання тих чи інших послуг.

А цінність «слухати і розказувати» забезпечується за рахунок щотижневих зустрічей, де керівники всіх відділів спілкуються між собою, обговорюють важливі питання, досягнення, синхронізуючи тим самим індрормацію по підприємству, яка дозволяє їм розуміти поняття, які можуть бути їм не близькі в силу відмінності специсріки діяльності відділів [8]. Це забезпечує не лише єдність в компанії, але й належне організування роботи усіх її відділів.

Доцільно зазначити, що цінності впливають і на склад колективу працівників, манеру їх поведінки, ставлення до роботи, норм, які обумовлені організацією. Наприклад, при підборі працівника на вакантну посаду, менеджери 3 персоналу радять перевіряти відповідність цінностей претендента цінностям компанії. Так, за результатами проведеного дослідження «Оцінка цінностей на етапі найму на Executive позиції» виявлено, що 76\% керівників вищого рівня управління щонайменше раз за останні 5 років приймали рішення про звільнення працівника через розбіжності його особистих життєвих та профресійних цінностей із цінностями компанії [9].

Корпоративна культура є дієвим інструментом мотивації персоналу, що підтверджується результатом проведених досліджень [10], а саме 85 \% мотивації працівників залежить від стабільності компанії на ринку, можливості кар'єрного зростання, принципів та цінностей, які сповідує організація, місця та ролі працівника в господарській діяльності підприємства.

Сильна корпоративна культура впливає на фрормування сприятливого психологічного клімату в колективі, забезпечує комфрортне робоче середовище, що спонукає працівників до досягнення результатів та цілей компанії. Це підтвердили дослідження серед працівників харчової, будівельної, вугільної промисловості, сорери освіти, послуг, торгівлі, наведені в [5], щодо ролі корпоративної культури в житті організації (рис. 3).

За даними дослідження, 52,6\% працівників стверджують, що сильна корпоративна культура забезпечує гармонійність стосунків у колективі, за умови дотримання прописаних цінностей, норм та принципів. А от $8 \%$ респондентів зазначило, що вдале її формування сприяє творчому розвитку працівників, а відповідно підвищенню рівня їх ініціативності та креативного підходу до вирішення поставлених завдань.

Рівень впливу корпоративної культури на мотивування працівників можна оцінити низкою показників, одним з яких $є$ рівень визнання.

Як стверджують 85\% керівників відділу кадрів, програма визнання співробітників компанії покращує їх корпоративну культуру, оскільки відкрите визнання, які відображають цінності компанії, зміцнює колектив, командний дух, і, звісно, культуру компанії [11; 12].

Статистика щодо впливу корпоративної культури вказує на те, що 69\% працівників 


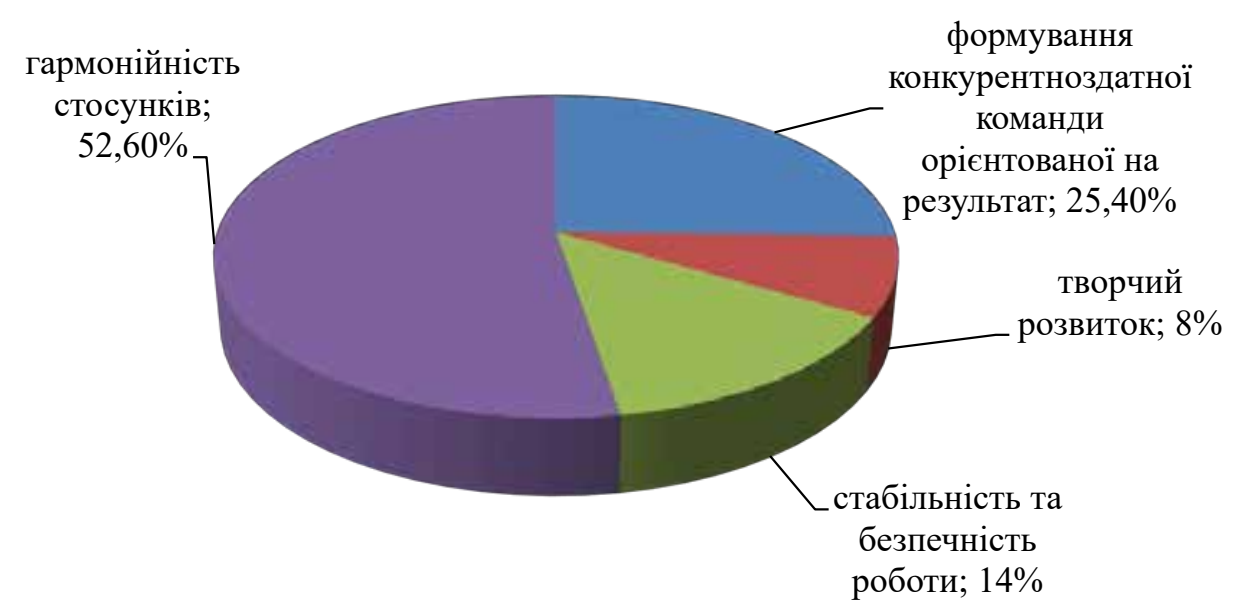

Рис. 3. Структура відповідей респондентів на питання «Сильна корпоративна культура у колективі забезпечує...» Джерело: [5]

працювали б краще і ефективніше, якби отримали визнання, оскільки залучені співробітники більш віддані своїй справі і докладають більше зусиль для досягнення цілей компанії. Визнання у колективі допомагає також зменшити плинність кадрів, зокрема 20\% компаній з корпоративною культурою, в яких увага зосереджується на цінності співробітників, мають на 31\% нижчий рівень плинності кадрів [13].

Не менш важливим індикатором корпоративної культури та її впливу на мотивування працівників $€$ показник залученості, який відображає рівень задоволення, прихильності до організації, її цінності, концентрації на виконанні завдань.

Як стверджують результати досліджень компаній Gallup i IBM Kenexa у [14], високий рівень залучення працівників у трудову діяльність організації на 17\% збільшує ефективність ведення бізнесу на ринку, на 20\% сприяють зростанню продаж, на 21\% - прибутку. Відповідно, за таких умов організації можуть досягнути п'ятикратного зростання вартості акцій в довгостроковій перспективі.

Яскравим прикладом впливу такої цінності як залученість $€$ діяльність компанії Fullers Brewery у ссрері послуг, яке налічує у штаті понад 4000 працівників. У 2019 році керівництво компанії зосередило свою увагу на двох ключових фракторах: розуміння та зростання ролі кожного працівника у діяльності організації та важливість врахування думки та голосу колективу. У результаті впроваджених змін, стосовно підходу до залучення робітників, компанія розширилась на 5\%, відкривши нові фрілії та збільшивши штаб, а прибуток зріс на 10\% [14].
Підтвердженням вагомого впливу залученості працівників на діяльність компаній є статистичні дані звіту Gallup 2020 року, де наведені такі дані [15; 16; 17; 18; 19]:

- низький рівень залученості працівників коштує бізнесу 450-500 млрд. дол. США на рік;

- щасливі працівники виробляють на 12\% більше, тоді як нещасливі - на 10\% менше;

- організації з високим гендерним розмаїттям і залученості співробітників досягають зростання фрінансових показників на 46-58\%;

- клієнти на 233\% ставляться лояльніше до компаній із залученими працівниками;

- компанії мають змогу збільшити прибуток на 2400 дол. США щороку, витрачаючи лише на 10\% більше у залучення працівників;

- залучені працівники пропускають 3 робочі дні в рік на відміну від осіб з низьким рівнем залученості, в яких пропуск становить 6 робочих днів.

- прогули в організаціях із низьким рівнем залученості персоналу складає в середньому $8 \%$, порівняно з 4\% в компаніях з високим рівнем залучення;

- у компаніях з рівнем залученості вище середнього спостерігається зростання прибутку на 2,06\% і рентабельності на 3,74\% протягом 3 років.

Роль корпоративної культури у процесі контролювання $€$ важливою, оскільки керівництво, здійснюючи контроль та проводячи оцінку діяльності, повинно дотримуватись задекларованих місії, бачення, цінностей, норм та правил. Таким чином, ключові елементи корпоративної культури є своєрідними нормативними еталонами, які слід дотримуватися і до яких слід прагнути. Водночас 
вони є індикаторами, які дозволяють оцінити відповідність, наприклад, цінностей працівника цінностям компанії з метою запобігання неузгодженості в діях, порушення принципів в роботі у команді, з клієнтами тощо. I при, виявленні відхилення, швидко відреагувати, регулюючи проблемні ситуації.

Висновки та перспективи подальших досліджень. Аналізуючи наукові дослідження та відгуки практиків щодо результатів покращення управлінських процесів внаслідок використання основних ключових елементів корпоративної культури в організаціях, зроблено висновок про те, що керівникам вітчизняних компаній варто більше уваги звертати на цей дієвий ідеологічний та інформаційний інструмент менеджменту. При цьому, слід запровадити механізм оцінювання рівня корпоративної культури та ії̈ впливу 3 метою посилення дієвості її використання, особливо з врахуванням життєвого циклу компанії, що і буде подальшою темою дослідження.

\section{СПИСОК ВИКОРИСТАНИХ ДЖЕРЕЛ:}

1. Кицак Т.Г. Вітчизняні реалії становлення корпоративної культури на підприємствах. Ефективна економіка. 2014. № 1. URL: http://www.economy.nayka.com.ua/?op=1\&z=2810

2. Офіційний сайт Forbes (2015) "Corporate Culture Matters A Lot, Says New Study". URL: https://mww.forbes.com/ sites/susanadams/2015/11/12/corporate-culture-matters-says-new-study/?sh=7f8d2df522b4

3. Офіційний сайт PWC (2016) 19-те Щорічне опитування керівників найбільш компаній світу. URL: https://www.pwc.com/ua/uk/survey/2016/19th-ceo-survey-ukr.pdf

4. Офіційний сайт FinancesOnline (2021) "75 Logo Statistics You Can't Ignore: 2021/2022 Data Analysis \& Market Share". URL: https://financesonline.com/logo-statistics/\#: :text=Logos\%20are\%20the\%20most\%20 recognizable,(Study\%20Finds\%2C\%202020)

5. Ринкевич Н.С. Організаційна культура підприємств: виклики, загрози та тенденції, Економічний вісник Донбасу. 2019. № 3(57). С. 123-136.

6. Ооріційний сайт Forbes (2011) "Does corporate culture drive financial performance?". URL: https://www.forbes.com/ sites/johnkotter/2011/02/10/does-corporate-culture-drive-financial-performance/?sh=7d1c40847e9e

7. Бойко О. Невидимі важелі впливу: корпоративні цінності - ефективний інструмент управління аудиторською компанією. Аудитор України. 2019. № 9(286).

8. Офріційний сайт компанії Work.ua (2022). URL: https://www.work.ua/about-us/

9. Ооріційний сайт блогу Executive (2021) Цінності та їхнє оцінювання: запорука взаємного успіху. URL: https://executives.com.ua/tsinnosti-ta-yikhnie-otsiniuvannia/amp/

10.Офіційний сайт Gallup (2016) "Few employees believe in their company`s values". URL: https://news.gallup.com/ businessjournal/195491/few-employees-believe-company-values.aspx

11. Ооріційний сайт компанії ApolloTechnical (2021) "17 employee recognition statistics that will make you think (2022)". URL: https://www.apollotechnical.com/employee-recognition-statistics/\#: :text=An\%20employee\%20 recognition\%20program\%20can,\%2C\%20employee\%20retention\%2C\%20and\%20health.\&text=Employee\%20recognition\%20programs\%20benefit\%20organizational,they\%20positively\%20affect\%20organizational\%20 culture

12. Офріційний сайт блогу Vantage Circle (2021) "7 Effects of Emloyee recognition on Business". URL: https://blog.vantagecircle.com/effects-of-employee-recognition-on-business/

13.Офріційний сайт Semos Cloud (2019) "What are Employee Recognition Programs". URL: https://semoscloud.com/ blog/employee-recognition-program-benefits-ideas/

14. Офіційний сайт Forbes (2018), "Общее дело. Почему в России и США разный уровень вовлеченности сотрудников". URL: https://www.forbes.ru/karera-i-svoy-biznes/363359-obshchee-delo-pochemu-v-rossii-i-ssharaznyy-uroven-vovlechennosti

15. Офріційний сайт Gallup (2021) "A global pandemic. And its impact on global engagement, stress and the workforce". URL: https://www.gallup.com/workplace/349484/state-of-the-global-workplace.aspx\#ite-350777

16.Офіційний сайт Gallup (2021) "Achievers engagement and Retention Report". URL: https://www.achievers.com/ wp-content/uploads/2021/03/Achievers-Workforce-Institute-2021-Engagement-and-Retention-Report.pdf

17. Офіційний сайт блогу (2021) TeamStage "Employee Engagement Statistics: Does It Increase Productivity in 2022?". URL: https://teamstage.io/employee-engagement-statistics/

18.Офріційний сайт Builttn (2021) "41 Stats on the smportance of employee engagement". URL: https://builtin.com/ employee-engagement/employee-engagement-statistics

19. Офріційний сайт компанії ТопФактор (2018) "Как вовлеченность сотрудников влияет на ваш бізнес". URL: https://topfactor.pro/blog/Kak-vovlechennost-sotrudnikov-vliyaet-na-vash-biznes/ 


\section{REFERENCES:}

1. Kytsak T.H. (2014) "Reality formation domestic corporate culture on enterprieses". Efektyvna ekonomika [Online], no. 1. Available at: http://www.economy.nayka.com.ua/?op=1\&z=2810

2. The official site of Forbes (2015) "Corporate Culture Matters A Lot, Says New Study". Available at: https://www.forbes.com/sites/susanadams/2015/11/12/corporate-culture-matters-says-new-study/?sh=7f8d2df522b4

3. The official site of PWC (2016) "19-te Schorichne opytuvannia kerivnykiv najbil'sh kompanij svitu" [19 $19^{\text {th }}$ Annual survey of executives of the world's largest companies]. Available at: https://www.pwc.com/ua/uk/survey/2016/19thceo-survey-ukr.pdf

4. The official site of FinancesOnline (2021) "75 Logo Statistics You Can't Ignore: 2021/2022 Data Analysis \& Market Share\}. Available at: https://financesonline.com/logo-statistics/\#: :text=Logos\%20are\%20the\%20most\%20 recognizable,(Study\%20Finds\%2C\%202020)

5. Rynkevych N.S. (2019) "Organizational culture of enterprises: challenges, threats and trends". Ekonomichnyj visnyk Donbasu, no. 3(57), pp. 123-136.

6. The official site of Forbes (2011) "Does corporate culture drive financial performance?". Available at: https://www.forbes.com/sites/johnkotter/2011/02/10/does-corporate-culture-drive-financial-performance/?sh=7d$1 \mathrm{c} 40847 \mathrm{e} 9 \mathrm{e}$

7. Bojko O. (2019) Invisible levers of influence: corporate values are an effective tool for managing of the audit company, Audytor Ukrainy, no. 9(286).

8. The official site of company Work.ua (2022). Available at: https://www.work.ua/about-us/

9. The official site of blog Executive (2021) "Tsinnosti ta ikhnie otsiniuvannia: zaporuka vzaiemnoho uspikhu" [Values and their assessment: the key to mutual success]. Available at: https://executives.com.ua/tsinnosti-ta-yikhnie-otsiniuvannia/amp/

10. The official site of Gallup (2016) "Few employees believe in their company's values". Available at: https://news.gallup.com/businessjournal/195491/few-employees-believe-company-values.aspx

11. The official site of company ApolloTechnical (2021) "17 employee recognition statistics that will make you think (2022)". Available at: https://www.apollotechnical.com/employee-recognition-statistics/\#: :text=An\%20employee \%20recognition\%20 program \%20can, $\% 2 \mathrm{C} \% 20$ employee $\% 20$ retention $\% 2 \mathrm{C} \% 20$ and\%20health.\&text=Employee\%20recognition\%20programs\%20benefit\%20organizational,they\%20positively\%20affect\%20organizational\%20culture

12. The official site of blog Vantage Circle (2021) "7 Effects of Emloyee recognition on Business". Available at: https://blog.vantagecircle.com/effects-of-employee-recognition-on-business/

13. The official site of Semos Cloud (2019) "What are Employee Recognition Programs". Available at: https://semoscloud.com/blog/employee-recognition-program-benefits-ideas/

14. The official site of Forbes (2018) "Obschee delo. Pochemu v Rossyy y SShA raznyj uroven' vovlechennosty sotrudnykov" [Common cause. Why there are different levels of employee involvement in Russia and in the USA]. Available at: https://www.forbes.ru/karera-i-svoy-biznes/363359-obshchee-delo-pochemu-v-rossii-i-ssha-raznyy-uroven-vovlechennosti

15. The official site of Gallup (2021) "A global pandemic. And its impact on global engagement, stress and the workforce". Available at: https://www.gallup.com/workplace/349484/state-of-the-global-workplace.aspx\#ite-350777

16. The official site of Gallup (2021) "Achievers engagement and Retention Report". Available at: https://www.achievers.com/wp-content/uploads/2021/03/Achievers-Workforce-Institute-2021-Engagement-and-Retention-Report.pdf

17. The official site of TeamStage (2021) "Employee Engagement Statistics: Does It Increase Productivity in 2022?". Available at: https://teamstage.io/employee-engagement-statistics/

18. The official site of Builtln (2021) "41 Stats on the smportance of employee engagement". Available at: https://builtin.com/employee-engagement/employee-engagement-statistics

19. The official site of TopFaktor (2018) "Kak vovlechennost' sotrudnykov vlyiaet na vash biznes" [How employee engagement influences your business]. Available at: https://topfactor.pro/blog/Kak-vovlechennost-sotrudnikov-vliyaet-na-vash-biznes/ 